Historic, Archive Document

Do not assume content reflects current scientific knowledge, policies, or practices. 



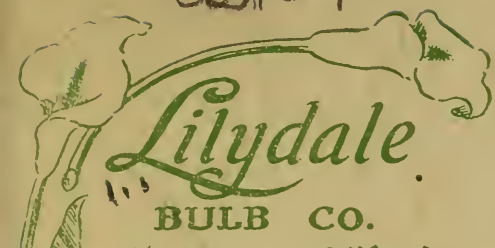

Santa eruz, California.

OUR SRECIALTIES:

Calla Bulbs (White)

Yellow Callas (Elliotiana)

Freesias (Purity)

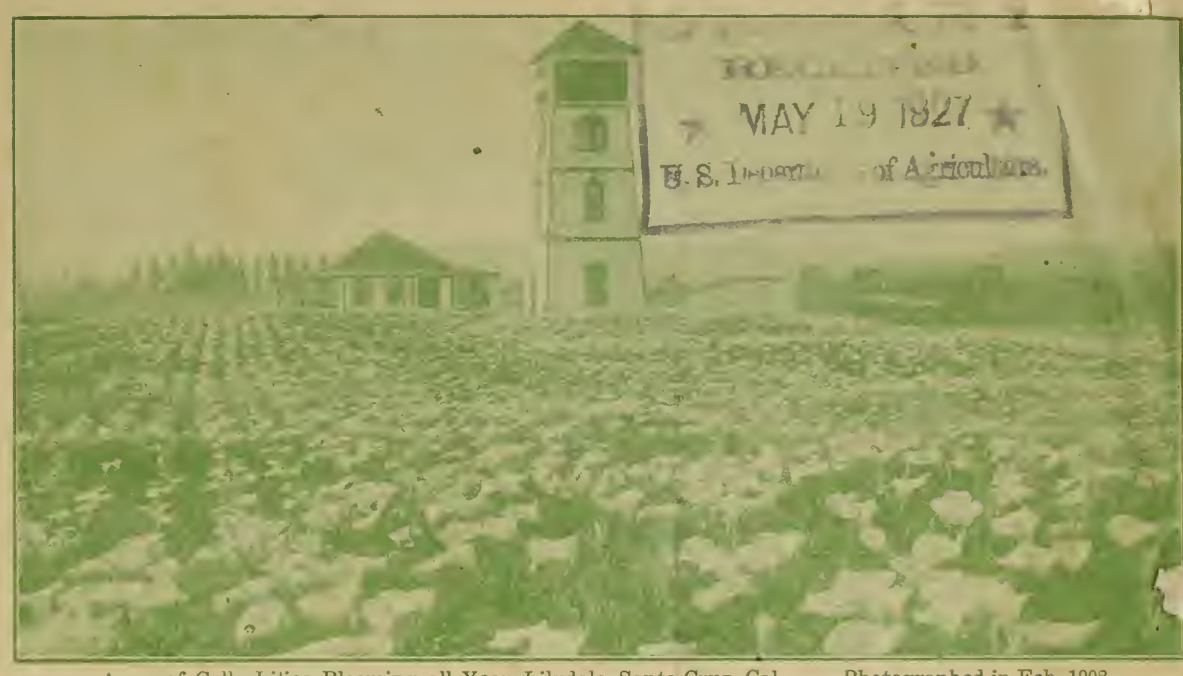

Acres of Calla Lilies Blooming all Year, Lilydale, Santa Cruz, Cal.

Photographed in Feb. 1908

Santa Cruz, June 28, 1913.

Gentlemen:-

We beg to quote ycu as follows on Freesia bulbs (true Fisher's Purity), for immedia delivery, viz:-

"Purity" Freesia Bulbs-

per 1000

IMammoth

$\$ 15.00$

1st Size ( $1 / 2$ to $5 / 8$ in. diameter)

8.50

2nd Size ( $1 / 4$ to $3 / 8$ in. diameter)

4.00

On the 1st and 2nd sizes we will make a $5 \%$ discount on 50,000 lots, and $10 \%$ discount 100,000 lots. No discount on the Mammoths, which we have in limited quantity, and will divi among customers buying first and second sizes. These prices are for delivery to you by expre or mail, cash with order.

For delivery from July 15 th to September 1 st we will have the following bulbs, all A-1 quali true stock, viz:-

Callas (white) ( 3 to $5 \frac{1}{2}$ in. circumference).

Allium Neapolitanum

Tulips, Gesneriana (true).

\section{NARCISSUS -}

Trumpet Major

Incomparable Sir Watkin

Princeps

Paper White (Grandifiora)

Poeticus Ornatus

Poeticus (Pheasant's Eye)

Alba Plena Odorata (double Poeticus)

GLADIOLUS-

Bride (Colvilla Alba)

Peach Blossom

IXIAS-

Blushing Bride

Achievement (cream)

Gracchus (yellow)

Hogarth (red)

Fairy Queen (red and white).

If interested in any of the above bulbs please write us for prices.

Foping to hear from you with an order or an inquiry, we are,

Very truly yours, 
